\title{
The predatory mite Phytoseiulus macropilis (Acari: Phytoseiidae) occurring on sweet potato (Ipomoea batatas) plants in Diamantina, Minas Gerais State, Brazil
}

\author{
Castro, BMC. ${ }^{a}$, Soares, MA. ${ }^{a *}$, Andrade Júnior, VC. ${ }^{a}$, Fadini, MAM. ${ }^{b}$, \\ Ferreira, JAM. ${ }^{c}$ and Moraes, GJ. ${ }^{d}$ \begin{abstract}
Rodovia MGT 367, Km 583, 5000, Alto da Jacuba, CEP 39100-000, Diamantina, MG, Brazil
bUniversidade Federal de São João Del-Rei - UFSJ, Rodovia MG 424, Km 47, Itapuã, CP 56, CEP 35701-970, Sete Lagoas, MG, Brazil

'Departamento de Entomologia, Universidade Federal de Viçosa - UFV, Campus Universitário, CEP 36570-000, Viçosa, MG, Brazil

dDepartamento de Entomologia e Acarologia, Escola Superior de Agricultura "Luiz de Queiroz" - ESALQ, Universidade de São Paulo - USP, Av. Pádua Dias, 11, CP 09, CEP 13418-900, Piracicaba, SP, Brazil

*e-mail: marcusasoares@yahoo.com.br
\end{abstract} \\ a Departamento de Agronomia, Universidade Federal dos Vales do Jequitinhonha e Mucuri - UFVJM, Campus JK,
}

Received: July 16, 2013 - Accepted: September 26, 2013 - Distributed: August 31, 2014

Ipomoea batatas (L.) Lam. Convolvulaceae is quite a simple vegetable for growing because of its rusticity, high level of adaptation to different soil types and weather, higher tolerance to dry weather and low production cost (Cardoso et al., 2005). Due to its higher genetic variability, the sweet potato can be used for different kinds of purposes. (Gonçalves Neto et al., 2011; Neiva et al., 2011). It can be used as human and animal food and for food, fabric, paper, cosmetics, adhesives and alcohol industries (Cardoso et al., 2005). However, different species of pests and diseases can significantly decrease the production of this crop.

The aim of this research was to record the occurrence of a predatory mite associated with two species of phytophagous mites, Tetranychus ludeni Zacher, 1913 and Tetranychus urticae Koch, 1836 (Acari: Tetranychidae) on sweet potato plants.

The horticulture sector of the Federal University of the Jequitinhonha and Mucuri Valleys (Universidade Federal dos Vales do Jequitinhonha e Mucuri - UFVJM), in Diamantina, Minas Gerais state, Brazil, has a sweet potato germplasm bank kept in plastic pots and inside a greenhouse. The occurrence and attack of Tetranychidae mite species was observed in this germplasm bank during 2011 and caused severe damages and plant death (Soares et al., 2012).

During some surveys and samples on the plants from the sweet potato germplasm bank, we found a predatory mite species occurring in the same habitat as the phytophagous mites. Leaves of this plant species were randomly detached and transported to the Laboratory of Entomology of the Federal University of São João Del Rei (Universidade Federal de São João Del Rei - UFSJ), in Sete Lagoas, Minas Gerais state, Brazil. All the predatory mites were collected by a fine paintbrush, transferred and mounted in microscope slides using Hoyer medium (Jeppson et al., 1975). The microscope slides were kept on a hot plate $\left(60^{\circ} \mathrm{C}\right)$ during three days for drying.
Then, we sent the microscope slides to Dr. Gilberto José de Moraes, a Phytoseiidae taxonomist from the Escola Superior de Agricultura "Luiz de Queiroz" - ESALQUSP, in Piracicaba, São Paulo state, Brazil. The predatory mite was identified as Phytoseiulus macropilis (Banks, 1904) (Acari: Phytoseiidae). The specimens used for this identification are in the Mite Collection at ESALQ-USP.

Many other studies have demonstrated that the predatory mites of the Phytoseiidae family can effectively control the phytophagous mite population. The occurrence of these predators has already been recorded in other cities and plants, such as Lavras (Minas Gerais state, Brazil) on citrus (var. Valência) (Reis et al., 2000), in Jeriquara and Garça cities (São Paulo state, Brazil) on Coffea arabica L. cv Mundo Novo plants (Mineiro et al., 2006) and in Rio Grande do Sul state (Brazil) on soybean (Roggia et al., 2009) and strawberry plants (Ferla et al., 2007). In conclusion, this predatory mite has a potential as natural enemy that can be used to control phytophagous mites on sweet potato plants and until now is the only natural enemy recorded on this crop. This mite species can be easily and efficiently reared in laboratory conditions and should be considered in biological control programmes for phytophagous mites on sweet potato crops.

\section{References}

CARDOSO, AD., VIANA, AES., RAMOS, PAS., MATSUMOTO, SN., AMARAL, CLF., SEDIYAMA, T. and MORAIS, OM., 2005. Avaliação de clones de batata-doce em Vitória da Conquista. Horticultura Brasileira, vol. 23, no. 4, p. 911-914. http://dx.doi. org/10.1590/S0102-05362005000400009.

FERLA, NJ., MARCHETTI, MM. and GONÇALVES, D., 2007. Ácaros predadores (Acari) associados à cultura do morango (Fragaria sp., Rosaceae) e plantas próximas no Estado do Rio Grande do Sul. Biota Neotropica, vol. 7, no. 2, p. 1-8. http:// dx.doi.org/10.1590/S1676-06032007000200012. 
GONÇALVES-NETO, AC., MALUF, WR., GOMES, LAA., GONÇALVES, RJS., SILVA, VF. and LASMAR, A., 2011. Aptidões de genótipos de batata-doce para consumo humano, produção de etanol e alimentação animal. Pesquisa Agropecuaria Brasileira, vol. 46, no. 11, p. 1513-1520.

JEPPSON, LR., KEIFER, HH. and BAKER, EW., 1975. Mites injurious to economic plants. Berkeley: University of California Press. $614 \mathrm{p}$.

MINEIRO, JLC., SATO, ME., RAGA, A., ARTHUR, V., MORAES, GJ., SARRETA, FO. and CARRIJO, A., 2006. Diversidade de ácaros (Arachnida: Acari) em Coffea arabica L. cv. Mundo Novo, nos municípios de Jequiquara e Garça, Estado de São Paulo. Biota Neotropica, vol. 6, no. 2, p. 1-15. http://dx.doi.org/10.1590/ S1676-06032006000200012.

NEIVA, IP., ANDRADE-JÚNIOR, VC., VIANA, DJS., FIGUEIREDO, JA., MENDONÇA FILHO, CV., PARRELLA, RAC. and SANTOS, JB., 2011. Caracterização morfológica de acessos de batata-doce do banco de germoplasma da UFVJM,
Diamantina. Horticultura Brasileira, vol. 29, no. 4, p. 537-541. http://dx.doi.org/10.1590/S0102-05362011000400016.

REIS, PR., CHIAVEGATO, LG., ALVES, EB. and SOUSA, EO., 2000. Ácaros da família Phytoseiidae associados aos citros no município de Lavras, sul de Minas Gerais. Anais da Sociedade Entomológica do Brasil, vol. 29, no. 1, p. 95-104. http://dx.doi. org/10.1590/S0301-80592000000100012.

ROGGIA, S., GUEDES, JVC., ROGGIA, RCRK., VASCONCELOS, GJN., NAVIA, D. and DELALIBERA-JUNIOR, I., 2009. Ácaros predadores e o fungo Neozygites floridana associados a tetraniquídeos em soja no Rio Grande do Sul. Pesquisa Agropecuaria Brasileira, vol. 44, no. 1, p. 107-110. http://dx.doi.org/10.1590/ S0100-204X2009000100015.

SOARES, MA., CASTRO, BMC., ANDRADE-JÚNIOR, VC., ASSIS-JÚNIOR, SL. and PIRES, EM., 2012. Attack of two new spider mites on sweet potato (Ipomoea batatas) in Diamantina, Minas Gerais State, Brazil. Brazilian Journal of Biology, vol. 72, no. 4, p. 971. http://dx.doi.org/10.1590/S1519-69842012000500029. PMid:23295532 